Bourque, N. R., M.-A. Villard, M. J. Mazerolle, D. Amirault-Langlais, E. Tremblay, and S. Jolicoeur. 2015. Piping Plover response to coastal storms occurring during the nonbreeding season. Avian Conservation and Ecology 10(1): 12. http://dx.doi.org/10.5751/ACE-00734-100112

Copyright (C) 2015 by the author(s). Published here under license by the Resilience Alliance.

Research Paper

\title{
Piping Plover response to coastal storms occurring during the nonbreeding season
}

\author{
Nadine R. Bourque ${ }^{1}$, Marc-André Villard ${ }^{1}$, Marc J. Mazerolle ${ }^{2}$, Diane Amirault-Langlais ${ }^{3}$, Eric Tremblay ${ }^{4}$ and Serge Jolicoeur ${ }^{5}$ \\ ${ }^{1}$ Département de biologie, Université de Moncton, ${ }^{2}$ Centre d'étude de la forêt, Université du Québec en Abitibi-Témiscamingue, \\ ${ }^{3}$ Ecosystems Management Branch, Fisheries and Oceans Canada, Gulf Region, ${ }^{4}$ Unité du Nord du Nouveau-Brunswick, Parcs \\ Canada, ${ }^{5}$ Département d'histoire et de géographie, Université de Moncton
}

\begin{abstract}
The increase in coastal storm frequency and intensity expected under most climate change scenarios is likely to substantially modify beach configuration and associated habitats. This study aimed to analyze the impact of coastal storms on a nesting population of the endangered Piping Plover (Charadrius melodus melodus) in southeastern New Brunswick, Canada. Previous studies have shown that numbers of nesting Piping Plovers may increase following storms that create new nesting habitat at individual beaches. However, to our knowledge, no test of this pattern has been conducted over a regional scale. We hypothesized that Piping Plover abundance would increase after large coastal storms occurring during the nonbreeding season. However, we expected a delay in the colonization of newly created habitat owing to low-density populations, combined with high site fidelity of adults and high variability in survival rate of subadults. We tested this hypothesis using a 27-year (1986-2012) data set of Piping Plover abundance and productivity (nesting pairs and fledged young) collected at five sites in eastern New Brunswick. We identified 11 major storms that could potentially have modified Piping Plover habitat over the study period. The number of fledged young increased three years after a major storm, but the relationship was much weaker for the number of nesting pairs. These findings are consistent with the hypothesized increase in suitable habitat after coastal storms. Including storm occurrence with other factors influencing habitat quality will enhance Piping Plover conservation strategies.
\end{abstract}

\section{Réponse du Pluvier siffleur aux tempêtes côtières survenant en dehors de la saison de reproduction}

RÉSUMÉ. L'augmentation de la fréquence et de l'intensité des tempêtes côtières prévue dans la plupart des scénarios de changements climatiques modifiera vraisemblablement la configuration des plages et les milieux associés de façon substantielle. L'objectif de la présente étude était d'analyser l'impact des tempêtes côtières sur une population nicheuse du Pluvier siffleur (Charadrius melodus melodus), espèce en voie de disparition, dans le sud-est du Nouveau-Brunswick, au Canada. Des recherches antérieures ont montré que le nombre de Pluviers siffleurs nicheurs pourrait augmenter à la suite de tempêtes susceptibles de créer de nouveaux milieux de nidification sur certaines plages. Toutefois, selon nos connaissances, il n'y a eu aucun test de cette tendance à l'échelle régionale. Nous avons testé l'hypothèse selon laquelle l'abondance de ce pluvier augmenterait à la suite de tempêtes côtières importantes survenant en dehors de la saison de reproduction. Cependant, nous nous attendions à un décalage dans la colonisation des nouveaux milieux créés en raison de la faible densité des populations, combinée à la grande fidélité au site des adultes et au taux de survie très variable observé chez les jeunes. Nous avons analysé un jeu de données de 27 années (1986-2012) comprenant l'abondance et la productivité (couples nicheurs et jeunes aptes au vol) du Pluvier siffleur, récoltées à cinq sites dans le sud-est du Nouveau-Brunswick. Nous avons identifié onze tempêtes nous paraissant suffisamment importantes pour modifier l'habitat du Pluvier siffleur au cours de la période de l'étude. Le nombre de jeunes ayant pris leur envol a augmenté 3 ans après une tempête importante, mais la relation avec le nombre de couples nicheurs était beaucoup plus faible. Ces résultats concordent avec l'augmentation supposée du nombre de milieux de nidification propices consécutive aux tempêtes côtières. L'inclusion de l'occurrence de tempêtes avec les autres facteurs qui influent sur la qualité de l'habitat permettra d'améliorer les stratégies de conservation du Pluvier siffleur.

Key Words: Charadrius melodus melodus; coastal storms; natural disturbance; nesting habitat; New Brunswick; population trends; species at risk

\section{INTRODUCTION}

Among the challenges facing conservation planners, predicting impacts of climate-driven changes in habitat availability and suitability are becoming increasingly important. For example, many bird species nest in coastal areas and may face the direct and indirect effects of coastal storms and flooding (Hanson et al. 2006,
Convertino et al. 2011). Some of these effects include nest loss; mortality, primarily of nestlings; and abandonment of historical sites or occupation of new areas in response to storm-induced habitat changes (Michener et al. 1997). Thus, recurrent, abiotic factors such as storms and flooding must be explicitly integrated into conservation strategies (e.g., Aiello-Lammens et al. 2011). 
The Piping Plover (Charadrius melodus melodus) is listed as endangered under Schedule 1 of the Species at Risk Act (COSEWIC 2013). The 2006 International Piping Plover Census estimated the eastern Canada Piping Plover population at 460 adults, which corresponds to a decline of $4.3 \%$ since 2001 and 9.6\% since the 1991 census (Goossen and Amirault-Langlais 2010). Numerous studies have described Piping Plover distribution, abundance, and habitat use, as well as factors affecting productivity throughout North America (Haig and Oring 1985, Burger 1987, Flemming et al. 1992, Loegering and Fraser 1995, Rioux et al. 2011). However, little is known about the potential influence of coastal storms during the nonbreeding season on Piping Plover habitat and breeding populations. Storms during the breeding season can flood nests, result in unfledged chick mortality, and negatively alter breeding habitat (Chiasson et al. 1994, Tremblay et al. 2006, Environment Canada 2012). Conversely, extreme storm events, particularly those occurring outside the breeding season, i.e., fall or winter, can create ideal Piping Plover nesting habitat while possibly favoring access to foraging sites for juveniles (Burger 1987, Cohen et al. 2009, Environment Canada 2012). Overwashes and breaches created during severe storms facilitate access to ephemeral pools and bay tidal flats (Loegering and Fraser 1995). Moreover, these relatively flat areas are characterized by sparse vegetation and extensive cover of sand, pebbles, and shell fragments, which are favored by Piping Plovers for nesting and raising their broods (Flemming et al. 1992, Elias et al. 2000, Boyne et al. 2014). These habitat features are often created and maintained by fall or winter storms (Elias et al. 2000). When barrier islands or sand spits stabilize, vegetation encroachment results in a narrower beach where Piping Plovers may be forced to nest closer to the mean high water line. This increases the risk of flooding during extreme high tides and impedes access to backshores and tidal bay flats.

We used a long-term data set to relate coastal storms and Piping Plover abundance and productivity along the Northumberland Strait in New Brunswick, Canada. We investigated the relationship between coastal storms and habitat creation on five beaches with suitable habitat where Piping Plovers have been monitored for 27 years. Specifically, we examined whether Piping Plover abundance changed over the short or medium term in response to storm events. We hypothesized that major coastal storms during the nonbreeding season would create suitable habitat for Piping Plover by producing optimal nesting microhabitat, i.e., sparsely vegetated beach habitat interspersed with cobble, pebble, shell, or seaweed fragments, and facilitating access for unfledged young to important foraging habitat. We also predicted a delayed response to such storms because the quantity of Piping Plover habitat available in eastern Canada is not a factor limiting recovery of the species (Environment Canada 2012). Hence, we expected that low-density populations combined with high site fidelity of adults, as well as high variability in survival rate of subadults (Calvert et al. 2006, Cohen and Gratto-Trevor 2011), would cause delays in colonization of newly created nesting habitat. Through inspection of aerial photographs, we also investigated the dynamics of Piping Plover habitat creation by storms taking place during the nonbreeding season and habitat loss by natural revegetation. A better understanding of coastal storm effects on Piping Plovers and their habitat is critical to population modeling and conservation of this endangered species.

\section{METHODS}

\section{Study area}

Data were collected on beaches that are subject to regular monitoring for Piping Plovers nesting along the Northumberland Strait in Kent County, New Brunswick, Canada (Fig. 1) and that were occupied by at least one nesting pair between 1986 and 2012. Six beaches, representing a total length of $25 \mathrm{~km}$, were located in Kouchibouguac National Park (KNP), where annual Piping Plover surveys have been conducted since 1985 (Tremblay et al. 1992, 2006). Three additional beaches, Dune de Bouctouche (12 $\mathrm{km})$, Pointe-Sapin $(3.4 \mathrm{~km})$, and Escuminac $(12 \mathrm{~km})$, have been regularly surveyed since 1991, the year of the first international census. To avoid or minimize gaps in our time series, we grouped beaches according to their proximity; orientation; beach type, i.e., sand spit, barrier island, or mainland beach; beach profile; and exposure to predators and human disturbance. Following this treatment, we obtained five sites, i.e., groups of beaches, that were considered for the analyses.

Fig. 1. Map of the study area, showing the five study sites (beaches). Inset (center right): location of the tide-gauge stations referred to in the text: $\mathrm{E}$ and $\mathrm{PdC}$ denote tide-gauge stations at Escuminac and Pointe-du-Chêne, respectively.

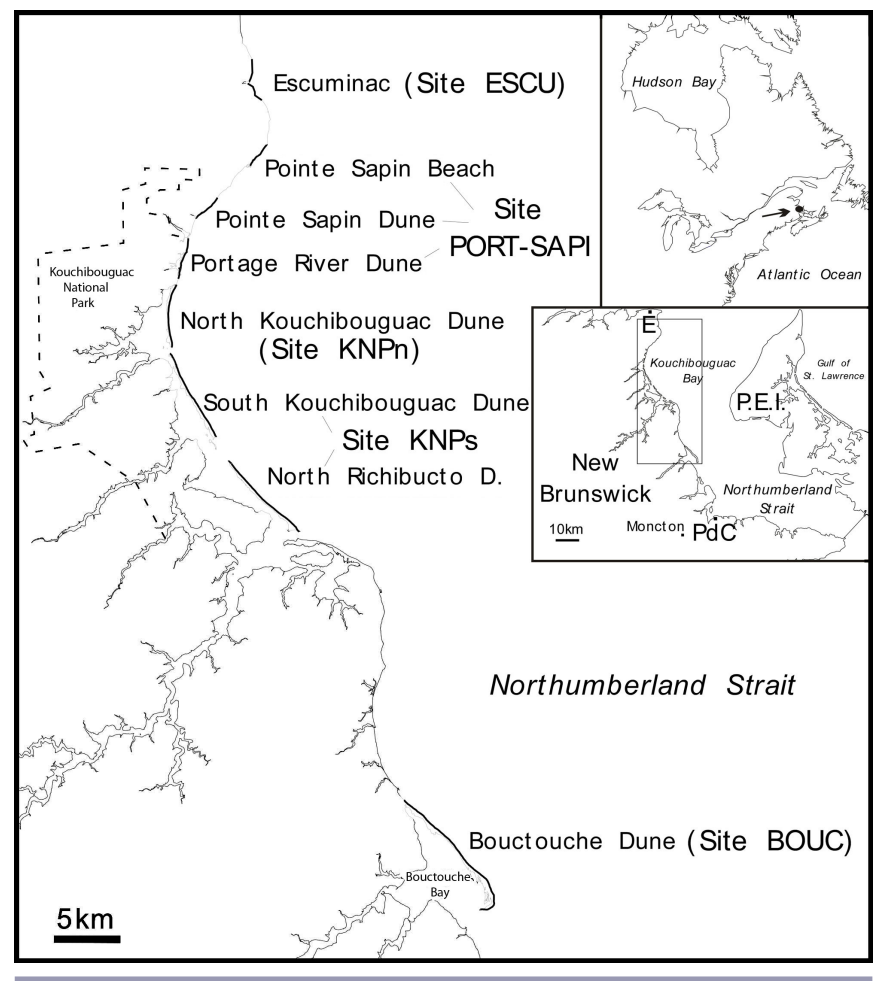

Beach orientation was calculated using the Soft Map software (http://www.softmap.com/) with digital topographic maps of Canada. Beach type and profile were identified using the provincial database on coastal erosion (Bérubé and Thibault 1996) and annual Piping Plover reports. Exposure to nest predators and human disturbance at each beach was estimated by observers and reported in the New Brunswick Atlas of Piping Plover Beaches (Gautreau and Stewart 2008). 
Table 1. Type, orientation, and length of beaches at study sites in southeastern New Brunswick, Canada.

\begin{tabular}{|c|c|c|c|c|}
\hline Site & Beach & Beach type & $\begin{array}{l}\text { Beach orientation } \\
\text { (heading) }\end{array}$ & $\begin{array}{c}\text { Beach length } \\
(\mathrm{km})\end{array}$ \\
\hline BOUC & Bouctouche Dune & $\begin{array}{l}\text { Sand spit backed by dune and salt } \\
\text { marsh }\end{array}$ & $139(\mathrm{~S}-\mathrm{SE})$ & 12.2 \\
\hline \multirow[t]{2}{*}{ KNPs } & North Richibucto Dune (NRD) & $\begin{array}{l}\text { Barrier island backed by dune and } \\
\text { salt marsh }\end{array}$ & 139 (S-SE) & 16.4 \\
\hline & South Kouchibouguac Dune (SKD) & $\begin{array}{l}\text { Barrier island backed by dune and } \\
\text { salt marsh }\end{array}$ & 153 (S-SE) & 15.6 \\
\hline KNPn & North Kouchibouguac Dune (NKD) & $\begin{array}{l}\text { Sand spit backed by dune and salt } \\
\text { marsh }\end{array}$ & 185 (S-SW) & 7.1 \\
\hline \multirow[t]{3}{*}{ PORT-SAPI } & Portage River Dune (PRD) & $\begin{array}{l}\text { Barrier beach backed by mudflats } \\
\text { and a lagoon }\end{array}$ & 195 (S-SW) & 4.7 \\
\hline & Pointe-Sapin north (PSn) & Mainland beach & 225 (S-SW) & 2.9 \\
\hline & Pointe-Sapin south (PSs) & Mainland beach & 187 (S-SW) & 3.4 \\
\hline $\mathrm{ESCU}$ & Escuminac & $\begin{array}{l}\text { Barrier beach backed by } \\
\text { saltmarshes and ponds }\end{array}$ & $162(\mathrm{~S}-\mathrm{SE})$ & 12.3 \\
\hline
\end{tabular}

Piping Plover nesting habitat consists of sandy beaches with little or no slope and the presence of pebbles, stones, rocks, shell fragments, and sparse vegetation or bare ground (Cairns 1982, Burger 1987, Flemming et al. 1992, Boyne et al. 2014). Although all beaches selected for the study possess one or several of these characteristics, they have different upper beach profiles (Table 1). Pointe-Sapin beach is located on the mainland; Escuminac beach is backed by a peat bog and inland barrier ponds; KNP's PointeSapin Dune and Rivière-au-Portage beaches are backed by mudflats and peat bogs; North Kouchibouguac and Bouctouche dunes are sand spits; and South Kouchibouguac and North Richibouctou dunes are barrier islands. Both spits and barrier islands are backed by lagoons (Bérubé and Thibault 1996, Gautreau and Stewart 2008).

\section{Piping Plover data}

We used all available Piping Plover nesting pair counts conducted in the study area for the purposes of this study. At Kouchibouguac National Park, data have been collected by Park staff using a standardized protocol since 1986(Tremblay et al. 2006). Elsewhere in the study area, reliable data have been available since 1991 and 1993 for Bouctouche and Escuminac beaches, respectively. We consulted annual regional survey information compiled by the Canadian Wildlife Service (CWS) since 1994, as well as nongovernment agency information obtained through the Piping Plover Guardian Project from the Irving Eco-Center-la Dune de Bouctouche (hereafter IEC), established in 1999 (Tremblay et al. 1992, Amirault 2005, Calvert et al. 2006, Tremblay et al. 2006). Surveys are normally performed during the Piping Plover breeding season at least once a week by trained observers. During surveys, observers walk along the length of beaches, recording each individual observed and identifying pairs based on breeding behavior. Given the continuity of the sampling effort, surveys were deemed a sensitive measure of the true number of nesting pairs and fledged young (Gautreau and Stewart 2008).

Since 2000, Global Positioning System (GPS) coordinates were available for all plover nests. The GPS data were mapped using MapInfo to establish nest distribution in relation to beach configuration. All nesting population data were obtained from CWS in Sackville, New Brunswick, or from annual Piping Plover reports from KNP and the IEC.

\section{Weather data}

To examine the relationship between Piping Plover abundance and coastal storms, we first identified storms deemed to be severe by experts. A regional study on the impacts of sea level rise and climate change on the coastal zone of southeastern New Brunswick identified the 11 most important storm surges for Pointe-du-Chêne and Escuminac (Fig. 1), as well as the 10 highest water levels from both available tide gauge records between 1971 and 2005 (Pointe-du-Chêne) and 1973 and 2005 (Escuminac; Parkes et al. 2006). Storm data for the post-2005 period were obtained through the Department of Fisheries and Oceans, Canadian Hydrologic Service. We identified three major storm surges between 2007 and 2010. All weather events identified corresponded to (1) an important storm surge and (2) highest water levels recorded. Storm surges that did not coincide with high water levels were not considered in this study. Eleven storms fit these criteria between 1986 and 2012 (Table 2).

\section{Aerial photographs and satellite image interpretation}

The impacts of storms meeting the severe storm criteria on coastal ecosystems and beach configuration were examined using aerial photographs from 1989 to $2002(1: 10,000$ and 1:12,500) and satellite imagery from Google Earth for the period from 2003 to 2007. Satellite imagery for sites Bouctouche (BOUC), North Kouchibouguac Dune (KNPn), and Portage River/Pointe Sapin (PORT-SAPI) had sufficient resolution to allow the assessment of habitat characteristics with an accuracy comparable to that of aerial photographs (see Fig. 1 for all site codes). We compared site characteristics, i.e., beach width and substrate, between aerial photographs but more specifically before and after storms events. This allowed pinpointing the effects or lack thereof of erosion, such as delta creation, overwashes and breaches, or the revegetation of Piping Plover habitat. We also searched for evidence of nesting habitat creation at the tip of spits and barrier islands.

\section{Data analysis}

The number of Piping Plover pairs and fledged young at each site were examined between 1986 and 2012, representing a time series enabling detection of distribution shifts related to habitat creation. 
Table 2. Characteristics of the 11 fall/winter storms selected for this study, including maximum water level (MWL), storm surge height and tide cycle at time of MWL, wind direction/speed, and presence/absence of flooding. Location of tide-gauge stations is shown in Figure 1.

\begin{tabular}{|c|c|c|c|c|c|c|c|c|}
\hline & \multirow[t]{2}{*}{ Date of event } & \multicolumn{2}{|c|}{$\begin{array}{c}\text { Lower } \\
\text { Escuminac } \\
(\mathrm{TGS} \# 2000) \\
\end{array}$} & \multicolumn{2}{|c|}{$\begin{array}{l}\text { Pointe-du-Chêne } \\
\text { (TGS \#1805) }\end{array}$} & \multirow[t]{2}{*}{$\begin{array}{l}\text { Wind direction } \\
\text { (quadrant) and } \\
\text { speed }(\mathrm{km} / \mathrm{h})\end{array}$} & \multirow[t]{2}{*}{$\begin{array}{l}\text { Tide cycle } \\
\text { (LE/PdC) }\end{array}$} & \multirow[t]{2}{*}{$\begin{array}{c}\text { Flooding } \\
\text { of studied site }\end{array}$} \\
\hline & & $\begin{array}{c}\text { Water level } \\
(\mathrm{m})\end{array}$ & $\begin{array}{l}\text { Surge } \\
(\mathrm{m})\end{array}$ & $\begin{array}{l}\text { Water level } \\
\text { (m) }\end{array}$ & Surge (m) & & & \\
\hline 1. & 4 January 1986 & 2.23 & 1.37 & 2.80 & 1.87 & $\mathrm{~N},-$ & Low & no \\
\hline 2. & 22 November 1986 & 2.01 & 1.49 & 2.80 & 1.65 & $\mathrm{NE}, 130$ & Middle-Low & yes \\
\hline 3. & 21 November 1988 & 2.38 & 1.3 & 2.80 & 1.48 & NNE, 101 & High & yes \\
\hline 4. & 21 November 1989 & 1.82 & 1.15 & 2.63 & 1.41 &,- 89 & Low/High & yes \\
\hline 5. & 21 January 2000 & - & - & 3.62 & 2 & NE, - & High & no \\
\hline 6. & 29 October 2000 & 2.42 & 1.52 & - & - & NE, - & High & no \\
\hline 7. & 19 February 2004 & 2.40 & 1.04 & 3.08 & 1.61 & - & High & no \\
\hline 8. & 4 December 2007 & 2.39 & 0.96 & 2.74 & 1.43 & - & High & - \\
\hline 9. & 6 December 2010 & 1.95 & 0.57 & 2.36 & 0.78 & E-SE, & Middle/High & no \\
\hline 10. & 21-23 December 2010 & 2.72 & 1.81 & 3.19 & 1.82 & NE, 70 & Middle/High & yes \\
\hline 11. & 27-28 December 2010 & 2.56 & 1.80 & 2.88 & 1.87 & - & Low & yes \\
\hline
\end{tabular}

Tide-gauge data from Fisheries and Oceans Canada.

We used Poisson regression with a log link and random intercepts to model the counts as a function of the occurrence of storms outside the breeding season (Gelman and Hill 2007, Zuur et al. 2009). Here, we included the site factor as a random effect to account for the nested nature of the data, i.e., observations nested within each site. Piping Plover response to habitat change may be delayed owing to the time necessary for immigration to sites altered by storms, for the re-establishment of invertebrate prey species in sites altered by storms, or for other unknown reasons. Thus, we considered the potential delayed effect of storms by modeling abundance one, two, and three seasons after the occurrence of major storms. We coded storm occurrence as a dummy variable, because the number of storms in a given year ranged between zero and three. We used a different model for each of the three scenarios, i.e., occurrence of storms one, two, or three years prior to a given year. We also considered a null model consisting of the same random effect structure as the other models, but with only the intercept as a fixed effect. Maximum likelihood estimates for the Poisson models were obtained with the Laplace approximation using the lme 4 package in $\mathrm{R}$ (Bates et al. 2014, R Development Core Team 2014). We quantified the support in favor of each model based on the second-order Akaike information criterion ( $\mathrm{AIC}_{\mathrm{c}}$ ) and its associated measures with the AICcmodavg package (Burnham and Anderson 2002, Mazerolle 2014).

\section{RESULTS}

\section{Photo interpretation of storm effects}

October 2000 storm: sites BOUC, KNPn, and PORT-SAPI In contrast to the 1995 series, 2002 aerial photographs showed recent storm-related habitat creation at all site groups (Table 3 ). Apart from a breach and associated storm delta that formed in 1999, all other habitat changes were observed in 2002. The 2002 habitat changes were the result of a storm that occurred in
October 2000 . This storm, characterized by strong northeasterly winds, resulted in the second highest water levels recorded by the Escuminac tidal gauge $(2.4 \mathrm{~m})$ within the study period, although the storm did not coincide with the daily high tide. This single storm event reshaped the 1999 breach in the middle section of

Table 3. Frequencies of storm-related Piping Plover (Charadrius melodus melodus) potential habitat creation/no creation or revegetation, and Piping Plover potential habitat creation through littoral drift, as identified by photo interpretation in southeastern New Brunswick, Canada.

\begin{tabular}{lcccc}
\hline \hline $\begin{array}{l}\text { Time } \\
\text { period }\end{array}$ & $\begin{array}{c}\text { Storm-related } \\
\text { habitat } \\
\text { creation }\end{array}$ & $\begin{array}{c}\text { No storm- } \\
\text { related } \\
\text { habitat } \\
\text { creation }\end{array}$ & $\begin{array}{c}\text { Sites with } \\
\text { revegetation } \\
\text { of storm- } \\
\text { related } \\
\text { landforms }\end{array}$ & $\begin{array}{c}\text { Sites with } \\
\text { habitat } \\
\text { creation } \\
\text { (littoral drift) }\end{array}$ \\
\hline $1985-1989$ & 2 & 0 & 0 & 0 \\
$1989-1991$ & 0 & 1 & 2 & 0 \\
$1991-1995$ & 0 & 2 & 1 & 3 \\
$1995-2002$ & 5 & 0 & 0 & 0 \\
$2002-2005$ & 1 & 2 & 0 & 0 \\
Total & 8 & 5 & 3 & 3 \\
\hline
\end{tabular}

Bouctouche Dune (Fig. 2) and in the middle portion of North Kouchibouguac Dune (site KNPn, Fig. 3). Many overwashes were created, with distinct recent sand deposits scattered on the Bouctouche Dune and North Kouchibouguac Dune as well as on Portage River Dune (site PORT-SAPI).

February 2004 storm: sites KNPs, PORT-SAPI, and ESCU At site South Kouchibouguac Dune (KNPs), satellite imagery from 2005 showed a wide new breach on the northern end of site KNPs but few overwashes and sand deposits compared with the 2002 aerial photographs. On another portion of the same site, Kelly's Island showed signs of vegetation removal and more 
extensive bare sand surfaces in 2005 than were present in 2002 . Vegetation had not recolonized the site by 2010, and a geomorphic study confirmed the very dynamic nature of the substrate (Young 2009).

Fig. 2. Aerial photographs showing the evolution of the breach in the middle section of the Bouctouche Dune (site BOUC) from 1996 to 2000. Presence of a notch created by off-road vehicles in the dune front (1996), breach and storm delta developed at the same location (1999), and breach and storm delta as enlarged by the 29 October 2000 storm (2000). The lower right-hand photograph shows the same breach and storm delta in 2000 from an oblique view. 1996, Service New Brunswick 46506460. 1999 and 2000, Irving Eco-Center-la Dune de Bouctouche private series. Such breaches appear to result in higher productivity in Piping Plover (Charadrius melodus melodus) populations (see text).
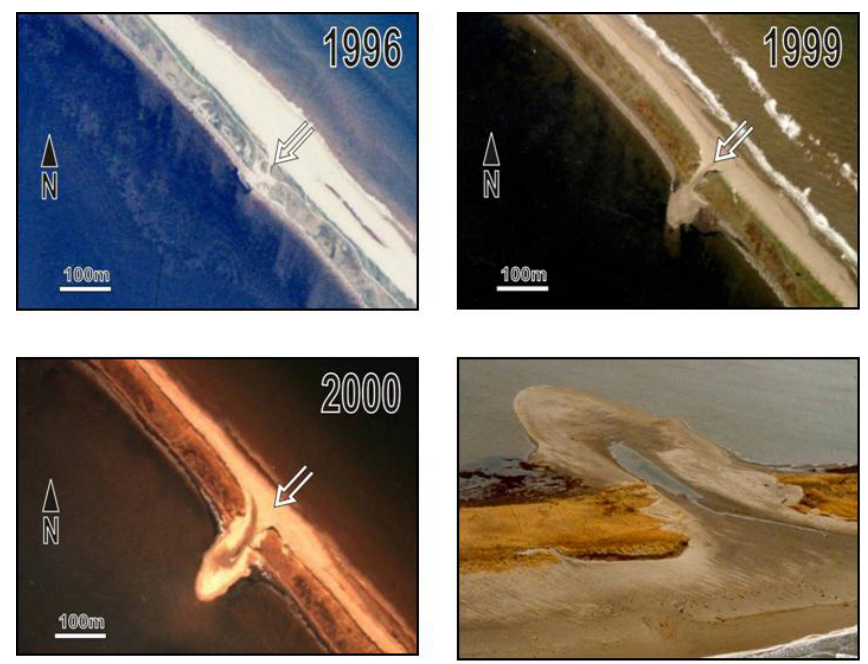

Fig. 3. Aerial photographs showing the middle section of North Kouchibouguac Dune (site KNPn) prior to and after the 29 October 2000 storm. 1995, NAPL A31728- 28, 1:10 000. 2002, DNR 02506-169, 1:12500.
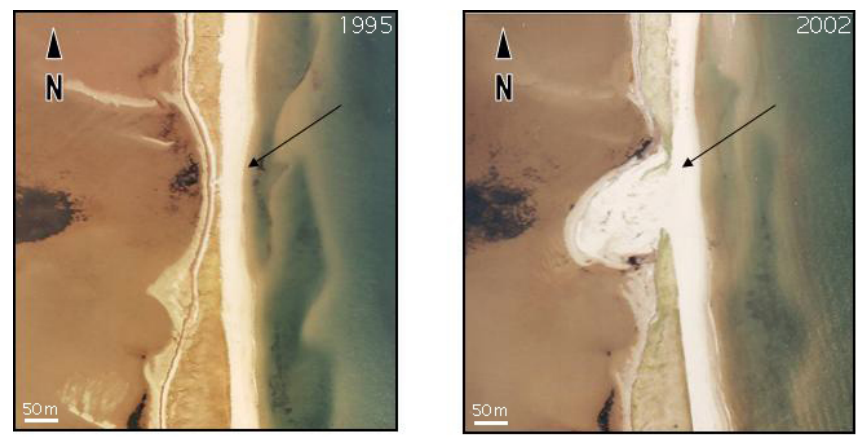

At sites PORT-SAPI and ESCU, the 2002 aerial photographs showed overwashes and large fresh sand surfaces on Portage River Dune and Pointe Sapin Dune (site PORT-SAPI) and Escuminac (site ESCU). Aerial photographs for site PORT-SAPI after 2002 were not available and satellite imagery after 2002 for both sites did not have sufficiently high resolution to confirm habitat changes.

\section{January and October 2000 storms: site KNPs}

The 2002 aerial photographs showed newly created habitat such as sand deposits and overwashes resulting from the October 2000 storm on South Kouchibouguac Dune and North Richiboucto Dune. However, the most prominent habitat change was the creation of a channel on the northern tip of South Kouchibouguac Dune (Fig. 4), and thus the formation of Kelly's Island. The accumulation of sand deposits was also noted on the southern tip of the barrier island.

Fig. 4. Aerial photographs showing the northern section of South Kouchibouguac Dune (site KNPs) prior to (1995) and after (2002) the 29 October 2000 storm. The development of an inlet through the northern tip of South Kouchibouguac Dune during the storm isolated a body of sand that is now known as Kelly's Island to the north. 1995, NAPL A31728-18, 1:10 000. 2002, DNR 02506-214, 1:12500.
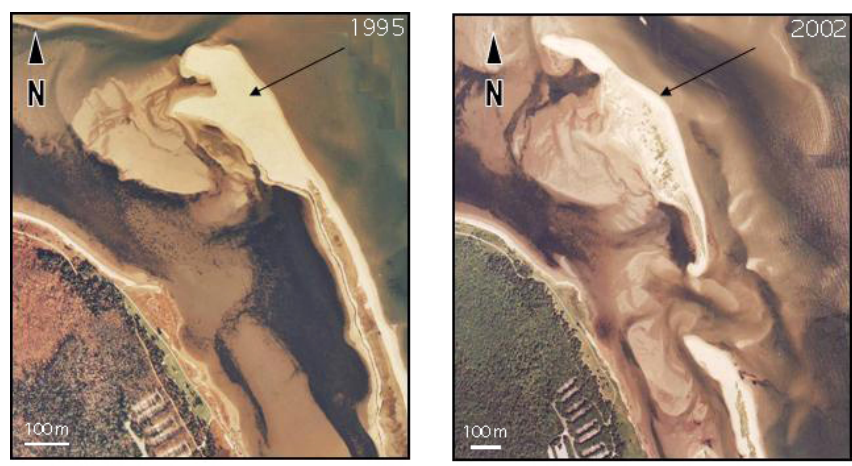

\section{Plover abundance and storm occurrence}

Among the five study sites, Piping Plover abundance ranged from 1 to 11 nesting pairs per year between 1986 and 2012, whereas the number of fledged young varied between 0 and 21 . Within our study period, the overall numbers were low or decreased early in the study period until the late 1990s and increased gradually until the mid-2000s before decreasing (Fig. 5).

When modeling nesting pair abundance, the top-ranked model included the storm occurrence variable lagged by three years, with $60 \%$ of the weight (Akaike weight $=0.60$ ), although the null model also had strong support (Table 4). Indeed, the top model was only 2.6 times more parsimonious than the null model, based on the evidence ratio of Akaike weights. The other two models, i.e., storm occurrence with a delay of one or two years, had less support. The top-ranked model suggested that the number of Piping Plover pairs counted three years after major storms was greater than in breeding seasons not preceded by a major storm three years earlier $\left(\beta_{\text {storm.lag } 3}=0.204,95 \%\right.$ profile likelihood confidence interval $[\mathrm{CI}]$ : $0.005,0.398)$. However, when accounting for model selection uncertainty and the support in favor of the null model, there were no indications of changes in nesting pairs relative to storm 
Table 4. Model selection results based on second-order Akaike information criterion ( $\mathrm{AIC}_{\mathrm{c}}$ ) on the number of Piping Plover (Charadrius melodus melodus) pairs and fledged young in five southeastern New Brunswick, Canada, sites between 1986 and 2012 . Note that $\Delta \mathrm{AIC}_{\mathrm{c}}$ measures the difference in $\mathrm{AIC}_{\mathrm{c}}$ between any model and the top-ranked model, whereas the Akaike weight is the probability that a given model is the most parsimonious.

\begin{tabular}{|c|c|c|c|c|c|}
\hline Response variable & Model & $\begin{array}{c}\text { Number of estimated } \\
\text { parameters }\end{array}$ & $\mathrm{AIC}_{\mathrm{c}}$ & $\Delta \mathrm{AIC}_{\mathrm{c}}$ & $\begin{array}{l}\text { Akaike } \\
\text { weight }\end{array}$ \\
\hline \multirow[t]{4}{*}{ Number of pairs } & $\begin{array}{l}\text { Occurrence of storm three seasons prior } \\
\text { to given year }\end{array}$ & 3 & 429.64 & 0 & 0.60 \\
\hline & Null model & 2 & 431.55 & 1.91 & 0.23 \\
\hline & $\begin{array}{l}\text { Occurrence of storm one season prior to } \\
\text { given year }\end{array}$ & 3 & 433.36 & 3.73 & 0.09 \\
\hline & $\begin{array}{l}\text { Occurrence of storm two seasons prior to } \\
\text { given year }\end{array}$ & 3 & 433.58 & 3.94 & 0.08 \\
\hline \multirow[t]{4}{*}{ Number of fledged young } & $\begin{array}{l}\text { Occurrence of storm three seasons prior } \\
\text { to given year }\end{array}$ & 3 & 685.63 & 0 & 1 \\
\hline & Null model & 2 & 698.12 & 12.48 & 0 \\
\hline & $\begin{array}{l}\text { Occurrence of storm one season prior to } \\
\text { given year }\end{array}$ & 3 & 698.62 & 12.99 & 0 \\
\hline & $\begin{array}{l}\text { Occurrence of storm two seasons prior to } \\
\text { given year }\end{array}$ & 3 & 699.05 & 13.42 & 0 \\
\hline
\end{tabular}

Fig. 5. Total number of Piping Plover (Charadrius melodus melodus) nesting pairs and fledged young at the study sites, 1986-2012, in southeastern New Brunswick, Canada. Arrows indicate the occurrence of storms relative to the breeding season.
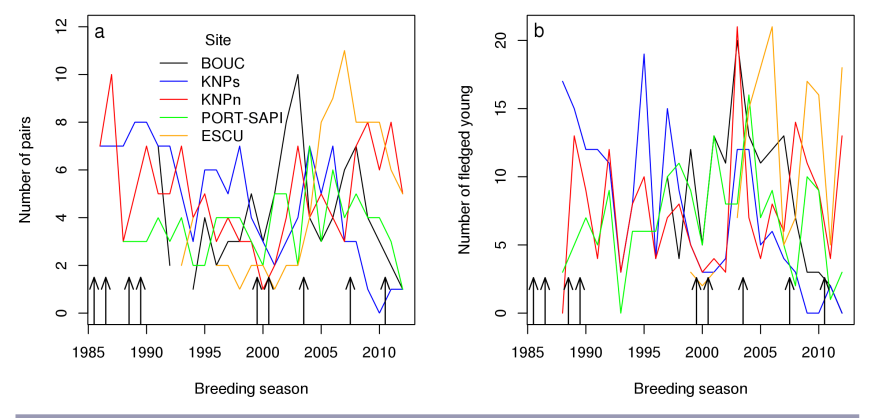

occurrence lagged by 3 years (model-averaged effect size on log scale: $0.121,95 \%$ CI: $-0.160,0.402$; Fig. 6a).

When considering the number of fledged young produced, the top-ranked model also consisted of storm occurrence lagged three years. Although the order of the models was identical to the nesting pair abundance data set, the most parsimonious model had all the support with an Akaike weight of 1 (Table 4). Indeed, the top model had 514 times more support than the null model, which ranked second. The number of fledged young produced was higher in breeding seasons three years after major storms than in breeding seasons that were not influenced by major storms three years earlier ( $\beta_{\text {storm.lag3 }}=0.289,95 \%$ profile CI: $0.142,0.433$; Fig. 6b). Because the top model had almost the entire support (Akaike weight $=1$ ), the model-averaged effect size for the difference in fledged young relative to storm occurrence lagged by 3 years was very similar to the beta estimate from the top model (0.287, 95\% CI: 0.081, 0.493).
Fig. 6. Model-averaged predictions of the number of Piping Plover (Charadrius melodus melodus) nesting pairs (a) and fledged young (b) at the study sites for a given breeding season in relation to the occurrence of storms three years earlier. Error bars denote $95 \%$ unconditional confidence intervals.
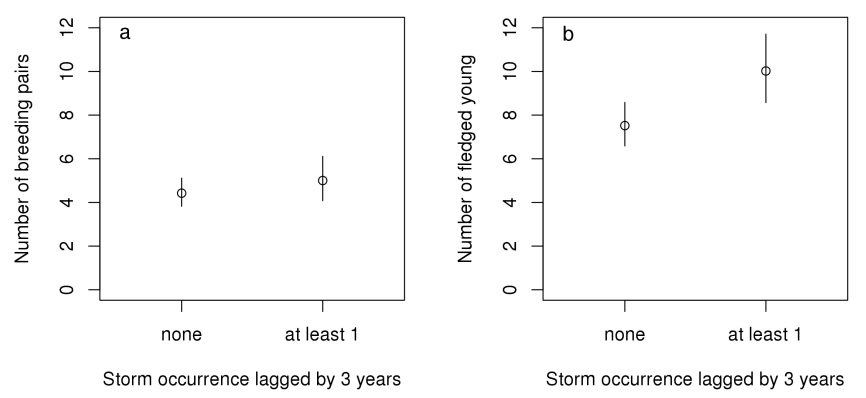

\section{DISCUSSION}

The number of fledged young increased three years after a major storm, but the relationship was much weaker for the number of nesting pairs. These findings are consistent with the hypothesized increase in suitable habitat after coastal storms, but the specific delay observed in Plover Plover response was unexpected.

\section{Effects of storms on Piping Plover habitat}

Storms that have the greatest impact on the coastlines of southeastern New Brunswick are usually associated with northeasterly winds, i.e., extratropical storms, which typically occur during late fall or early winter (Forbes et al. 2004). Wave energy during fall storms is at its maximum, whereas the impact of winter storms may be reduced by ice cover that diminishes wave energy, thereby affording natural coastal protection. Alternatively, fragmented icefeet (seasonal accumulation of ice on the beach at high-water mark) and drift ice can potentially accentuate impacts at the coast when mobilized by high tides and winter waves. Ice 
ride-up and pile-up can then transport sediment landward (Forbes et al. 2004). Storms occurring between mid-January and early March often have a negligible impact on coastal habitats because of ice cover protecting the shore from surge waves (Forbes et al. 2001, Forbes 2004, Parkes et al. 2006), although our data suggest that at least three winter storms altered beaches (Table 2, storms 5-7). Aerial photographs from 1989 show various overwashes, recent sand deposits, and breaches on sand spits and barrier islands at all five study sites. These coastal features may have been the result of storms recorded in January and November 1986 or in November 1988.

Cooper et al. (2004) suggested that only a small percentage of coastal storms are potentially damaging and lead to important geomorphological changes, especially those directed onshore and occurring simultaneously with a high tide. The clustering of storms should also be taken into account (Forbes et al. 2004). Finally, a storm may have different coastal impacts depending on beach orientation, tidal evolution, onshore wind direction, and seafloor topography (Cooper et al. 2004, Regnauld et al. 2004). Such detailed storm data were not available for this study, but storm complexity and coastal orientation could explain why certain storms resulted in habitat creation whereas others did not. Future studies would benefit from such data in predicting impacts on habitat under different storm scenarios.

The impacts of specific storms, such as in January 2000, cannot be singled out because they were sometimes quickly followed by subsequent storms. In addition, some high-profile beaches may be buffered from storms by ice cover, whereas some low coastal areas are more prone to flooding (Forbes et al. 2004). According to Parkes et al. (2006), certain areas along the southeastern coast of New Brunswick had ice piled up 3 or $4 \mathrm{~m}$ high after the January 2000 storm, resulting in direct ice damage, whereas coastal flooding occurred up to $1 \mathrm{~km}$ inland in other areas. The impact of a single storm on different coastal areas is therefore highly variable.

Habitat creation resulting from storms or habitat loss due to revegetation was difficult to detect because aerial photographs were not available in a continuous time series. Several storms sometimes occurred between years when aerial photographs were available (see also Cooper et al. 2004). For these reasons, it was often difficult to isolate the effects of specific storms on beaches and dunes. Reports from Kouchibouguac National Park and the Irving Eco-Center did not provide precise information on habitat creation or habitat loss, with the exception of the October 2000 storm. Because Piping Plovers readily disperse between breeding seasons (Amirault-Langlais et al. 2014), storms could also have created suitable nesting habitat outside the study area, leading to dispersal of nesting pairs to take advantage of newly created habitat (Haig and Oring 1988, Rioux et al. 2011).

\section{Storms and Piping Plover abundance}

To further investigate the lagged effects of storm occurrence on Piping Plover nesting pairs and fledged young, we included an a posteriori model with storm occurrence four years before the breeding season, i.e., four years earlier, in our model set. This model was equivalent to the three-year model for the number of adults, but the two models were closely followed by the null model. For the number of fledged young, however, the model with storm occurrence three years prior to the breeding season remained the top model with the entire support even after including a candidate model with storm occurrence four years earlier.

Several factors influence nesting habitat selection by Piping Plovers, including predation risk, weather, substrate type, habitat degradation and loss due to revegetation, and human disturbance. The fact that poststorm habitat creation does not immediately coincide with local increases in abundance may reflect a delay in the recruitment of breeding pairs, especially in an endangered species whose habitat does not appear to be saturated. In New York State, Cohen et al. (2009) reported population increases lasting more than a decade. This may reflect geomorphological beach attributes including the width, slope, number of breaches, and length of beaches that exceed those of our study sites. Biological factors also appear to play a significant role in determining the impacts of storms on Piping Plover abundance. Cohen et al. (2009) demonstrated that creation of combined nesting and adjacent foraging habitat was required to observe an increase in the number of Piping Plover nesting pairs. Therefore, the creation of suitable nesting habitat alone in our study would not have resulted in an immediate increase in Piping Plover abundance. The impacts of storms on the coastal invertebrate fauna, the preferred prey of Piping Plover, cannot be discounted. Several regional studies have demonstrated that invertebrate abundance is reduced after substrate disturbance (Shepherd and Boates 1999). The impacts of storms on invertebrate populations and the time required for recolonization of coastal areas following disturbance events are unclear, because our study did not address this question. Further research would be required to clarify this fine-scale impact of storms during the nonbreeding season. The latitudinal difference and its effect on the species pool of invertebrates, the presence of ice in our study area during four to five months of the year, and differences in coastal configuration and degree days may also influence the species composition and population dynamics of the invertebrate fauna (Defeo and McLachlan 2013) and in turn, the colonization of newly created habitat (Scapini 2014). Furthermore, the dynamics of Piping Plover populations in New York State may differ because nesting densities are much higher than those in Canada and because the U.S Atlantic coast Piping Plover population has recently experienced significant increases (Amirault 2005, Cohen et al. 2009).

A 20-year banding study on the Piping Plover showed that a major storm event followed by subsequent storms created long stretches of flat beaches and formed important breaches in the sand dunes (Wilcox 1959). The newly created habitat facilitated Piping Plover nesting, and its population reached a peak three years later. The number of nesting pairs was stable for another three years, but decreased thereafter when dunes were reconstructed to their prestorm configuration and beach grass was planted. A similar phenomenon was reported at St. Catherines River Beach, Nova Scotia (Wentzell 1997), where natural vegetation regrowth during a prolonged storm-free period reduced the amount of preferred nesting habitat. In New York State, Cohen et al. (2009) studied Piping Plover response to the creation and loss of habitat. Storms and beach nourishment increased the area suitable for nesting. A decrease in habitat quality followed as beach stabilization progressed, resulting in greater vegetation cover and a decrease in areas with exposed sand and pebbles. 
Cohen et al. (2009) predicted that nesting pair density would increase in relation to the area of moist sediment habitat available, e.g., mud flats, ephemeral pools. Interestingly, moist sediments are also created and maintained by storms. Beaches with a higher index of moist sediment habitat had higher densities of plover pairs and a higher density of neighbors, and individuals had smaller home ranges. Piping Plovers did not have to travel as far to forage and could reduce their home range size, thus making room for more territories (Cohen et al. 2009). If this phenomenon is applicable to eastern Canada, storms not only could recruit nesting pairs through the creation of nesting habitat, but also could increase carrying capacity and productivity if suitable foraging habitat is also created. Additional studies are needed to examine the relationship between foraging microhabitats, e.g. moist sediments, and Piping Plover densities in eastern Canada.

We did not examine either survival rates or dispersal for our specific study sites. Because the Piping Plover disperses readily on a regional scale in the Gulf of Saint Lawrence, it could be argued that the population trends we observed reflected a subset of results for a larger regional population. In Long Island, New York, 37\% of the nesting adults that were banded returned to their former breeding sites, and $8 \%$ of the banded fledged chicks returned. Those that did not return dispersed at a distance between 9 and $26 \mathrm{~km}$ (Wilcox 1959, Haig and Oring 1988). High nesting-site fidelity in Piping Plovers banded as adults has also been documented in eastern Canada (Amirault-Langlais et al. 2014). Consideration of dispersal patterns in both adult and juvenile Piping Plovers would be required to determine the influence of broader regional habitat changes on local shifts in numbers of nesting pairs. When comparing local nesting populations at the five study sites with the number of nesting pairs across the province as a whole from 1991 to 2012 (Fig. 7), we found that nesting pair abundance at our study sites followed the same general pattern as the New Brunswick population, albeit with smaller fluctuations.

Fig. 7. Total number of Piping Plover (Charadrius melodus melodus) nesting pairs in the study sites compared with numbers in the entire province of New Brunswick (NB) and eastern Canada from 1991 to 2012.

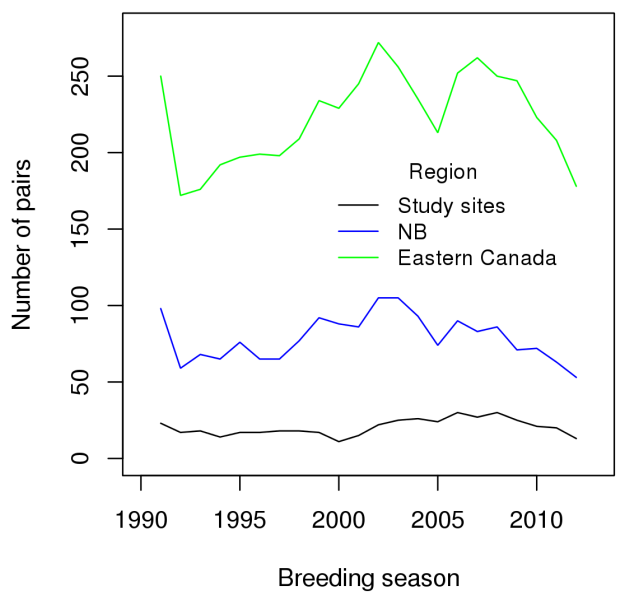

Our results suggest that winter storms contribute to short-term population increases through the creation of nesting habitat. Calvert et al. (2006) detected a slight short-term increase in nesting populations of the Gulf of Saint Lawrence during the 1998-2003 period $(\lambda=1,03$, assuming exponential growth), and our own data suggest that habitat creation following the October 2000 storm may partly account for this increase. This study illustrates how physical factors largely beyond the control of habitat managers can drive habitat availability for species of conservation interest. Hence, storm-related fluctuations of Piping Plover numerical responses should be considered along with humancaused shifts in habitat suitability when modeling Piping Plover population viability. Storms occurring during the nonbreeding season, especially those occurring three years prior to a breeding season, had a positive effect on the number of Piping Plover fledged young, but the number of nesting pairs did not vary substantially with this variable. Assuming that storms create highquality breeding habitat for Piping Plovers as well as adjacent foraging areas (Cohen et al. 2009), positive effects would also be expected on chick condition and long-term survival (Catlin et al. 2014). Including storm occurrence with other factors influencing habitat quality will enhance conservation strategies for Piping Plover.

Responses to this article can be read online at:

http://www.ace-eco.org/issues/responses.php/734

\section{Acknowledgments:}

We thank the numerous field workers who monitored Piping Plover populations across the study area. Special thanks to É. Tremblay for access to data from Kouchibouguac National Park and $R$. Stewart from Environment Canada. This project was supported by a grant from the New Brunswick Wildlife Trust Fund to SJ.

\section{LITERATURE CITED}

Aiello-Lammens, M. E., M. Librada Chu-Agor, M. Convertino, R. A. Fisher, I. Linkov, and H. R. Akçakaya. 2011. The impact of sea-level rise on Snowy Plovers in Florida: integrating geomorphological, habitat, and metapopulation models. Global Change Biology 17:3644-3654. http://dx.doi.org/10.1111/ j.1365-2486.2011.02497.x

Amirault, D. L., editor. 2005. The 2001 international Piping Plover census in Canada. Technical Report Series No. 436. Canadian Wildlife Service, Atlantic Region, Sackville, New Brunswick, Canada.

Amirault-Langlais, D. L., T. L. Imlay, and A. W. Boyne. 2014. Dispersal patterns suggest two breeding populations of Piping Plovers in Eastern Canada. Wilson Journal of Ornithology 126:352-359. http://dx.doi.org/10.1676/13-056.1

Bates, D., M. Maechler, B. Bolker, and S. Walker. 2014. lme4: linear mixed-effects models using Eigen and S4. R package version 1.1-6. [online] URL: http://CRAN.R-project.org/ package $=$ lme 4 
Bérubé, D., and J.-J. Thibault. 1996. Géomorphologie littorale du Détroit de Northumberland, sud-est du Nouveau-Brunswick. Geoscientific Report 96. Natural Resources Ministry and Energy New Brunswick, Department of Natural Resources and Energy, Mineral Resources, Fredericton, New Brunswick, Canada.

Boyne, A. W., D. L. Amirault-Langlais, and A. J. McCue. 2014. Characteristics of Piping Plover habitat in the Canadian maritime provinces. Northeastern Naturalist 21:164-173. http://dx.doi. org/10.1656/045.021.0202

Burger, J. 1987. Physical and social determinants of nest-site selection in Piping Plover in New Jersey. Condor 89:811-818. http://dx.doi.org/10.2307/1368529

Burnham, K. P., and Anderson, D. R. 2002. Model selection and multimodel inference: a practical information-theoretic approach. Springer-Verlag, New York, New York, USA.

Cairns, W. E. 1982. Biology and behavior of breeding Piping Plovers. Wilson Bulletin 94:531-545.

Calvert, A. M., D. L. Amirault, F. Shaffer, R. Elliot, A. Hanson, J. McKnight, and P. D. Taylor. 2006. Population assessment of an endangered shorebird: the Piping Plover (Charadrius melodus melodus) in eastern Canada. Avian Conservation and Ecology 1 (3): 4. [online] URL: http://www.ace-eco.org/vol1/iss3/art4/

Catlin, D. H., O. Milenkaya, K. L. Hunt, M. J. Friedrich, and J. D. Fraser. 2014. Can river management improve the piping plover's long-term survival on the Missouri River? Biological Conservation 180:196-205. http://dx.doi.org/10.1016/j.biocon.2014.10.004

Chiasson, R., B. Johnson, and E. Tremblay. 1994. The 1991 Piping Plover census in New Brunswick. Pages 20-23 in S. P. Flemming, editor. The 1991 international Piping Plover census in Canada. CWS Occasional Paper No. 82. Canadian Wildlife Service: 59. Canadian Wildlife Service, Ottawa, Ontario, Canada.

Cohen, J. B., and C. Gratto-Trevor. 2011. Survival, site fidelity, and the population dynamics of Piping Plovers in Saskatchewan. Journal of Field Ornithology 82:379-394. http://dx.doi. org/10.1111/j.1557-9263.2011.00341.X

Cohen, J. B., L. M. Houghton, and J. D. Fraser. 2009. Nesting density and reproductive success of Piping Plovers in response to storms-and human-created habitat changes. Wildlife Monographs 173:1-24. http://dx.doi.org/10.2193/2007-553

Committee on the Status of Endangered Wildlife in Canada (COSEWIC). 2013. COSEWIC assessment and status report on the Piping Plover circumcinctus subspecies (Charadrius melodus circumcinctus) and the melodus subspecies (Charadrius melodus melodus) in Canada. Committee on the Status of Endangered Wildlife in Canada, Ottawa, Canada. [online] URL: http://www. sararegistry.gc.ca/default.asp?lang=En\&n=BB6E4110-1

Convertino, M., J. B. Elsner, R. Muñoz-Carpena, G. A. Kiker, C. J. Martinez, R. A. Fisher, and I. Linkov. 2011. Do tropical cyclones shape shorebird habitat patterns? Biogeoclimatology of Snowy Plovers in Florida. PLoS ONE 6(1):e15683. http://dx.doi. org/10.1371/journal.pone.0015683

Cooper, J. A. G., D. W. T. Jackson, F. Navas, J. McKenna, and G. Malvarez. 2004. Identifying storm impacts on an embayed, highenergy coastline: examples from western Ireland. Marine Geology 210:261-280. http://dx.doi.org/10.1016/j.margeo.2004.05.012
Defeo, O., and A. McLachlan. 2013. Global patterns in sandy beach macrofauna: species richness, abundance, biomass and body size. Geomorphology 199:106-114. http://dx.doi.org/10.1016/ j.geomorph.2013.04.013

Elias, S. P., J. D. Fraser, and P. A. Buckley. 2000. Piping Plover brood foraging ecology on New York barrier islands. Journal of Wildlife Management 64:346-354. http://dx.doi.org/10.2307/3803232

Environment Canada. 2012. Recovery strategy for the Piping Plover (Charadrius melodus melodus) in Canada. Species at Risk Act. Recovery Strategy Series. Environment Canada, Ottawa, Ontario, Canada.

Flemming, S. P., R. D. Chiasson, and P. J. Austin-Smith. 1992. Piping Plover nest site selection in New Brunswick and Nova Scotia. Journal of Wildlife Management 56:578-583. http://dx.doi. org/10.2307/3808875

Forbes, D. L., G. S. Parkes, G. K. Manson, and L. A. Ketch. 2004. Storms and shoreline retreat in the southern Gulf of St. Lawrence. Marine Geology 210:169-204. http://dx.doi.org/10.1016/j. margeo.2004.05.009

Forbes, D. L., G. S. Parkes, R. B. Taylor, K. Thompson, C. O'Reilly, D. G. E. Liverman, N. Catto, and D. Bérubé. 2001. Coastal storm impacts in Atlantic Canada: three major storms of the year 2000. Abstracts Volume 26. Geological Association of Canada and Mineralogical Association of Canada, St John's, Newfoundland, Canada.

Gautreau, S., and J. Stewart. 2008. New Brunswick atlas of Piping Plover beaches. Fourth edition. Canadian Wildlife Service, Atlantic Region, Sackville, New Brunswick, Canada.

Gelman, A., and J. Hill. 2007. Data analysis using regression and multilevel/hierarchical models. Cambridge University Press, New York, New York, USA. http://dx.doi.org/10.1017/cbo9780511790942

Goossen, J. P., and D. L. Amirault-Langlais, editors. 2010. The 2006 international Piping Plover census in Canada. Technical Report Series No. 490. Canadian Wildlife Service, Prairie and Northern Region and Atlantic Region, Edmonton, Alberta and Sackville, New Brunswick, Canada.

Haig, S. M., and L. W. Oring. 1985. Distribution and status of the Piping Plover throughout the annual cycle. Journal of Field Ornithology 56:334-345.

Haig, S. M., and L. W. Oring. 1988. Distribution and dispersal in the Piping Plover. Auk 105:630-638.

Hanson, A., D. Forbes, D. Bérubé, S. O’Carroll, M. Mahoney, J. Ollerhead, L. Olsen, E. Tremblay, A. Boyne, S. Craik, R. Titman, J. Stewart, J. Strang, G. Parkes, D. Amirault, A. Calvert, and L. Swanson. 2006. Impacts on ecosystems. Section 4.6. Pages 402-481 in R. Daigle, editor. Impacts of sea level rise and climate change on the coastal zone of southeastern New Brunswick. Cat. no: En84-45/2006E, EPSM-753. Environment Canada, Dartmouth, Nova Scotia, Canada.

Loegering, J. P., and J. D. Fraser. 1995. Factors affecting Piping Plover chick survival in different brood-rearing habitats. Journal of Wildife Management 59:646-655. http://dx.doi.org/10.2307/3801940 
Avian Conservation and Ecology 10(1): 12

Mazerolle, M. J. 2014. AICcmodavg: model selection and multimodel inference based on (Q)AIC(c). R package version 2.01. [online] URL: http://CRAN.R-project.org/package= AICcmodavg

Michener, W. K., E. R. Blood, K. L. Bildstein, M. M. Brinson, and L. R. Gardner. 1997. Climate change, hurricanes and tropical storms, and rising sea level in coastal wetlands. Ecological Applications 7:770-801. http://dx.doi.org/10.1890/1051-0761 (1997)007[0770:CCHATS]2.0.CO;2

Parkes, G. S., G. K. Manson, R. Chagnon, and L. A. Ketch. 2006. Storm-surge, wind, wave and ice climatology. Section 4.2. Pages 95-262 in R. Daigle, editor. Impacts of sea level rise and climate change on the coastal zone of southeastern New Brunswick. Cat. no: En84-45/2006E, EPSM-753. Environment Canada, Dartmouth, Nova Scotia, Canada.

R Development Core Team. 2014. R: a language and environment for statistical computing. R Project for Statistical Computing, Vienna, Austria. [online] URL: http://www.R-project.org/

Regnauld, H., P. A. Pirazzoli, G. Morvan, and M. Ruz. 2004. Impacts of storms and evolution of the coastline in western France. Marine Geology 210:325-337. http://dx.doi.org/10.1016/ j.margeo.2004.05.014

Rioux, S., D. L. Amirault-Langlais, and F. Shaffer. 2011. Piping Plovers make decisions regarding dispersal based on personal and public information in a variable coastal ecosystem. Journal of Field Ornithology 82:32-43. http://dx.doi.org/10.1111/

j.1557-9263.2010.00305.x

Scapini, F. 2014. Behaviour of mobile macrofauna is a key factor in beach ecology as response to rapid environmental changes. Estuarine, Coastal and Shelf Science 150:36-44. http://dx.doi. org/10.1016/j.ecss.2013.11.001

Shepherd, P. C. F., and J. S. Boates. 1999. Effects of a commercial baitworm harvest on Semipalmated Sandpipers and their prey in the Bay of Fundy Hemispheric Shorebird Reserve. Conservation Biology 13:347-356. http://dx.doi.org/10.1046/j.1523-1739.1999.013002347. $\mathrm{x}$

Tremblay, E., N. Fontaine, and L. Richard. 1992. Restoring population of Piping Plover (Charadrius melodus) in Kouchibouguac National Park, Kouchibouguac, New Brunswick, Canada. Pages 25-30 in N. Lopoukhine, editor. Ecological restoration of national parks. Proceedings of a symposium at the fourth annual conference of the Society for Ecological Restoration. University of Waterloo, Waterloo, Ontario, Canada.

Tremblay, E., A. Hanson, and G. Parkes. 2006. Impacts of storm surge on Piping Plover nesting success at Kouchibouguac National Park. Section 4.6.9. Pages 466-476 in R. Daigle, editor. Impacts of sea level rise and climate change on the coastal zone of southeastern New Brunswick. Cat. no: En84-45/2006E, EPSM-753. Environment Canada, Dartmouth, Nova Scotia, Canada.
Wentzell, N. 1997. Piping Plover habitat manipulation proposal. Seaside Adjunct, Kejimkujik National Park, Nova Scotia, Canada.

Wilcox, L. R. 1959. A twenty year banding study of the Piping Plover. Auk 76:129-152. http://dx.doi.org/10.2307/4081772

Young, A. 2009. Sediment processes influencing the coastline of Kouchibouguac National Park, New Brunswick. Thesis. University of New Brunswick, Fredericton, New Brunswick, Canada

Zuur, A. F., E. N. Ieno, N. J. Walker, A. A. Saveliev, and G. M. Smith. 2009. Mixed effects models and extensions in ecology with $R$. Springer, New York, New York, USA. http://dx.doi. org/10.1007/978-0-387-87458-6
Editor-in-Chief: Ryan Norris Subject Editor: Erica Nol
Sponsored by the Society of Canadian Ornithologists and Bird Studies Canada Parrainée par la Société des ornithologistes du Canada et Études d'oiseaux Canada

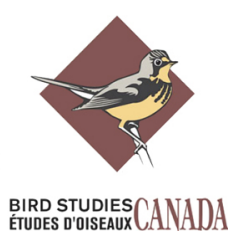

